\title{
TEKS UBAT BEDIL: PENGETAHUAN TEKSTUAL TENTANG UBAT BEDIL MELAYU
}

\author{
(“TEKS UBAT BEDIL”: THE TEXTUAL KNOWLEDGE OF \\ GUNPOWDER USE BY THE MALAYS)
}

\author{
Wan Mohd Dasuki Wan Hasbullah \\ wandasuki@um.edu.my \\ Eizah Mat Hussain \\ eizah@um.edu.my \\ Mohd Taufik Arridzo Mohd Balwi \\ taufik@um.edu.my \\ Akademi Pengajian Melayu \\ Universiti Malaya, Kuala Lumpur \\ Malaysia
}

Received: 8th September 2021; Accepted: 4th Oktober 2021;

Published: 26th October 2021

\begin{abstract}
The knowledge of firearms is one of the genres found in Malay manuscripts. However, gunpowder texts documented in such manuscripts have been largely elusive. This article aims to bridge the widening knowledge gap by presenting several textual evidence on the Malay tradition of using gunpowder. Using the philological research method, this article presents the transliteration of two texts found. Additionally, this paper intends to discuss content related to instructive and quantitative discourses. Therefore, this study is expected to provide a clearer picture of the textual dynamics of gunpowder knowledge to highlight the importance of the texts. Subsequently a discussion on the aforementioned manuscripts where specific gunpowder mixtures were explicitly stated will be considered as a concerted effort to enhance the understanding of Malay gun technology and facilitate in-depth discussions on various aspects of the traditional texts associated with the transmission of traditional knowledge, particularly in the form of quantitative or numerical descriptions.
\end{abstract}

Keywords: Malay manuscripts, gunpowder text, traditional knowledge, textual dynamics, instructive and quantitative texts.

\footnotetext{
Abstrak

Umum mengetahui bahawa ilmu bedil merupakan antara penulisan atau teks yang dapat ditemukan dalam manuskrip Melayu. Namun begitu, kajian-kajian mengenai teks ubat bedil sebagai satu daripada aspek teks atau pengisian karya ilmu bedil, sehingga kini masih belum mendapat perhatian yang wajar. Artikel ini berhasrat untuk merapatkan jurang 
pengetahuan yang semakin melebar berhubung hal ini, dengan mengemukakan beberapa bukti tekstual mengenai ubat bedil. Dengan bersandarkan metode penelitan filologi, artikel ini menampilkan hasil transliterasi dua buah teks yang ditemukan, selain membincangkan isi kandungannya melalui wacana instruktif dan kuantitatif. Hal yang demikian akan memberikan gambaran yang lebih jelas tentang dinamika teks ubat bedil yang mengandungi sukatan ramuan spesifik serta menonjolkan kepentingan teks-teksnya dalam menggalurkan diskusi baharu tentang manuskrip berkaitan. Usaha ini dianggap tidak hanya bertujuan meningkatkan lagi kefahaman tentang teknologi bedil Melayu, malah membincangkan dengan lebih dalam aspek-aspek tradisi penurunan teks yang terkait dengan satu daripada bentuk keilmuan tradisional, khasnya yang bersifat kuantitatif atau numerikal.

Kata Kunci: manuskrip Melayu, teks ubat bedil, ilmu tradisional, dinamika tekstual, teks instruktif dan kuantitatif.

\section{Pengenalan}

Masyarakat Melayu kaya dengan pelbagai khazanah warisan silam, sama ada dalam bentuk legasi budaya kebendaan mahupun bukan kebendaan (Mohd Anuar et al., 2016, p. 181). Salah satu legasi bukan bersifat kebendaan ini ialah ilmu tentang penggunaan senjata api yang turut tercatat dalam manuskrip-manuskrip Melayu atau sekarang lebih popular disebut dengan nama 'ilmu bedil'. Manuskrip-manuskrip yang memuatkan subjek tentang senjata api memperlihatkan kemahiran dan kepakaran orang Melayu dalam mendeskripsikan kaedah pengendalian bedil, yang sebenarnya lebih merujuk pada senjata api ringan (senapang). Deskripsi ini berkisar cara-cara mengisi peluru dan ubat bedil, memposisikan bedil, membidik, serta melepaskan tembakan. Hampir keseluruhan cara itu sudah tentu diiringi dengan pembacaan mantera, bahkan turut dikaitkan dengan pengkisahan mitos yang menawarkan pengertian yang lebih rumit tentang hubungan ilmu atau perkakas material bedil dengan sifat-sifat sakral (Wan Mohd Dasuki, 2013). Dengan demikian, di sebalik bentuk penulisannya yang seakan-akan pedoman (treatise) itu, teks ilmu bedil menyuakan informasi yang padat mengenai soal-soal kearifan, pemikiran, kepercayaan, falsafah atau tradisi lisan, dan terangkum dalam mod wacana yang bersifat instruktif. Dalam pengertian ini, teks ilmu bedil telah dianggap merupakan sebahagian daripada hasil persuratan tradisional yang berkonsepkan kepustakaan ilmu (Harun et al., 2006).

\section{Sorotan Kajian}

Kajian-kajian tentang teks ilmu bedil semakin berkembang sejak akhir-akhir ini. Semakin ramai peneliti yang melibatkan diri mengkaji teks ilmu bedil dalam pelbagai bidang dan perspektif. Terenjit Sevea (2020) sebagai contoh, merupakan antara peneliti mutakhir yang menggunakan sejumlah teks ilmu bedil untuk memahami kedudukan pengetahuan tentang persenjataan itu dalam kegiatan sosioekonomi masyarakat di negeri-negeri Melayu sebelah pantai barat. Ada pula antara pengkaji itu yang meneliti aspek-aspek bahasa dalam teksteks seperti kajian yang dilakukan Nor Farhana et al. (2018). Dalam kajian yang lain, Pramono et al. (2015) mengetengahkan unsur-unsur mistik tasawuf yang berkaitan dengan penggunaan bedil. Namun begitu, dapat dinyatakan bahawa pengetahuan tentang teks dan manuskrip ilmu bedil belum lagi tersusun dengan lebih jelas terutama dari segi isi 
kandungannya. Tambahan pula, dikatakan bahawa teks-teks tersebut masih banyak yang belum ditemukan. Bahan-bahan teks yang ada sekarang pula tidak lengkap sehingga menyebabkan beberapa bahagian perbincangan isi kandungan ilmu bedil sebagai sebuah hasil persuratan tradisional dianggap masih kabur. Satu daripadanya adalah keterangan mengenai ubat bedil.

Kajian-kajian mengenai teks ubat bedil sebagai satu daripada aspek teks atau pengisian dalam karya ilmu bedil Melayu sehingga kini masih belum meluas berbanding aspek-aspek lain, apatah lagi jika ingin memberikan sebuah interpretasi terhadap proses pembuatan ubat bedil. Wan Mohd Dasuki melalui kajiannya $(2012,2013)$ memperlihatkan buat pertama kali bahawa dalam teks ilmu bedil turut terkandung keterangan tentang ramuan membuat ubat bedil. Walau bagaimanapun, didapati hanya sebuah sahaja sumber yang dimaksudkan, iaitu manuskrip 85.48 yang tersimpan di Lembaga Muzium Negeri Terengganu, Malaysia. Dalam kajian-kajian terdahulu, Wan Mohd Dasuki memberikan penjelasan tentang sifat-sifat ubat bedil yang tertulis dalam 85.48, termasuk menukarkan sistem timbangan dan sukatan tradisional seperti tahil, kati, paha, emas dan sebagainya. Berdasarkan penukaran sistem timbangan itu dikatakan bahawa sepucuk bedil istinggar dapat melepaskan tembakan melebihi 800 meter, menunjukkan tentang jarak yang paling ideal dicapai oleh senapang orang Melayu dalam memanifestasikan kekuatan tembakan menurut kapasiti ubat bedil yang telah disusun meskipun berat pelurunya tidak diketahui (Wan Mohd Dasuki, 2013, p. 205).

Namun begitu, dengan hanya menggunakan sebuah teks, pandangan itu nampaknya harus dirapikan lagi dan disokong dengan berbagai-bagai sumber lain, sehingga kini, belum diperlihatkan melalui mana-mana tulisan. Dapat dikatakan juga bahawa sungguhpun teks ilmu bedil kini semakin banyak diperhatikan orang, catatan tentang pembuatan ubat bedil menurut manuskrip tersebut masih kurang dibicarakan hingga pandangan-pandangan awal berhubung konsep ubat bedil, sukatan bahan, begitu juga dengan sejarah mengenainya tenggelam begitu sahaja (Wan Mohd Dasuki et al., 2012). Kekosongan dalam perbincangan ini amat jelas dalam kajian-kajian mutakhir termasuk yang berkait dengan aspek-aspek persenjataan atau peperangan orang Melayu. Hal ini adalah sebagaimana yang dapat diperhatikan menerusi diskusi Muhamad Shafiq (2020, p. 51-52). Penjelasan tentang penggunaan ubat bedil dalam memahami konteks teknologi dan situasi peperangan tersebut tidak pernah dibutirkan dengan menggunakan manuskrip-manuskrip seperti ini. Situasi yang sama dapat diperhatikan dalam perbincangan-perbincangan mengenai kerangka epistemologi Melayu dalam hubungannya dengan konsep sains sebagai contoh (Norafifah et al., 2011). Informasi berhubung teknologi bedil dan ubat bedil dalam manuskrip-manuskrip ini tidak pernah dipertimbangkan sebagai data kajian.

\section{Matlamat dan Kepentingan}

Artikel ini ditulis dengan tujuan untuk merepresentasikan dua contoh teks ubat bedil yang telah ditemukan dalam usaha untuk memperlihatkan bentuk dan sifat teks, serta menggariskan beberapa aspek isi kandungannya yang perlu ditangani daripada sudut tekstual manuskrip itu sendiri. Representasi teks ubat bedil ini dijangkakan dapat memberikan gambaran yang lebih jelas tentang dinamika tekstual, terutama dengan mengambil kira hubungan antara kedua-dua teks dalam memahami konteksnya. Pemahaman yang lebih jitu berhubung teks dan konteks wacana instruktifnya dijangkakan dapat mempercambahkan lagi potensi dan minat penelitian, bukan hanya terhadap aspek- 
aspek penurunan tradisi keilmuan tradisional Melayu tentang persenjataan, bahkan subjek ubat bedil itu sendiri yang menjadi sebahagian daripada warisan kearifan lokal yang sudah hilang. Teks ubat bedil berfungsi sebagai dokumen yang mampu mendekati bentuk pemikiran atau nilai kearifan masyarakat dalam kaitannya dengan adaptasi ilmu dan teknologi, khasnya senjata api.

\section{Kaedah Kajian}

Pengesanan bahan teks dilakukan dengan menggunakan beberapa katalog manuskrip terpilih, di samping maklumat inventarisasi yang diperoleh dalam kajian-kajian lepas, sehingga dapat menemukan beberapa judul manuskrip yang berkaitan dengan aspek-aspek persenjataan dan bedil. Namun begitu, ketetapan telah dibuat sejak awal untuk tidak memilih dan menilai teks-teks naratif (hikayat peperangan) yang banyak sekali jumlahnya, kecuali hanya teks-teks manuskrip berbentuk ilmu atau pedoman. Berdasarkan katalog Ricklefs et al., (2014, yang sebelum itu diterbitkan pada 1977) telah ditemukan kata 'gunpowder' (ubat bedil) dalam beberapa bahan. Pemeriksaan ke atas bahan bernombor MS 36497 mendapati sejumlah muka surat di bahagian belakang manuskrip memuatkan deskripsi tentang pembuatan ubat bedil. Sebelum itu, pemeriksaan turut dilakukan terhadap sejumlah manuskrip yang diperkirakan mengandungi deskripsi ilmu bedil. Namun begitu, setakat ini hanya ditemukan bahan bernombor 85.48 sahaja yang memiliki keterangan yang terperinci tentang ubat bedil. Manuskrip ini terdaftar dalam Katalog Induk Manuskrip Melayu (1993). Dalam bacaan awal, dapat dikesan beberapa persamaan isi kandungannya dengan teks ubat bedil dalam MS 36497. Dengan adanya persamaan ini, kedua-dua buah manuskrip tersebut dipilih sebagai bahan penelitian.

Selaras dengan matlamat untuk menyajikan teks, pendekatan filologi digunakan, dengan erti kata sebagai suatu usaha kritis ke atas bahan-bahan manuskrip itu. Teks-teks ubat bedil dalam kedua-dua manuskrip itu dibaca dan ditransliterasi kata demi kata. Kemudian penyelarasan bacaan dilakukan, dengan memperhatikan bentuk ejaan dan kesesuaian bunyi sebutan serta makna katanya mengikut konteks yang dibincangkan. Tidak ada bacaan teks yang rumit ditemukan atau hal yang bersifat luar biasa dalam salinan kedua-dua manuskrip tersebut. Justeru, pembaikan teks dilakukan secara minimum dengan memberikan informasi berhubung penggunaan kata-kata tertentu dalam beberapa bahagian teks, terutama maknanya. Penyediaan hasil transliterasi teks ini, yang sebaik mungkin cuba mengekalkan struktur ayat dan sebutan kata yang asal, diharapkan dapat menjadi rujukan silang dalam membincangkan isi kandungannya. Perbincangan mengenai isi kandungan teks manuskrip-manuskrip itu pula dilakukan dengan menjelaskan tentang (a) bentuk dan sifat wacana teksnya, (b) aspek-aspek ramuan ubat bedil, dan (c) aspekaspek kuantitatif ramuan itu seperti angka dan sukatannya.

\section{Deskripsi Manuskrip}

Setakat ini telah ditemukan dua buah manuskrip yang berbeza tetapi berisi perbincangan yang hampir sama tentang pembuatan ubat bedil. Manuskrip-manuskrip yang dimaksudkan ialah MS 36497 (selepas ini dirujuk dengan nama Adat Segala Raja-raja Melayu dan diringkaskan sebagai 'Adat' sahaja) dan 85.48 (dirujuk dengan nama Petua Menembak Meriam Istinggar dan diringkaskan sebagai 'Petua'). Berikut dinyatakan secara lebih terperinci tentang kedua-dua bahan manuskrip berkenaan. 


\section{MS 36497 (Adat)}

Manuskrip ini diberikan judul 'Adat Segala Raja-raja Melayu', merupakan suatu bahan yang tersimpan di Perpustakaan School of Oriental and African Studies (SOAS), Universiti London (Ricklefs et al., 2014). Berdasarkan judulnya, dapat dikatakan bahawa manuskrip ini terkenal dan telah diteliti oleh ramai pengkaji, antaranya Panuti Sudjiman untuk tesis kedoktorannya (1979). Sudjiman menyebut bahawa Adat merupakan satu daripada sepuluh versi teks Adat Raja-raja Melayu (yang dinyatakannya sebagai versi A-J). Versi ini dirujuk sebagai manuskrip D (Sudjiman, 1979, p. 25). Berdasarkan kajiannya, manuskrip D memiliki kaitan erat dengan empat buah lagi manuskrip, iaitu versi B (von de Wall 64 di Museum Pusat Lembaga Kebudayaan Indonesia), C (MS 21042 di SOAS), E (MS 41407 di SOAS) dan J (Maxwell 60 di Royal Asiatic Society, London). Perkaitan ini dirujuk daripada segi tambahan kandungan selepas teks utama, termasuk deskripsi tentang ubat bedil. Dengan erti kata lain, menerusi kajian Sudjiman (1979) menunjukkan teks ubat bedil terkandung dalam lima versi teks Adat Raja-raja Melayu, iaitu versi B, C, D, E dan J. Berdasarkan kajian lepas, teks ubat bedil dalam bahan-bahan yang disebutkan setakat ini belum lagi dikaji, kecuali oleh Sudjiman dengan mengemukakan hasil transliterasi teks dalam tesisnya (Sudjiman, 1979, p. 224-226).

Berdasarkan tinjauan terhadap Adat, keseluruhan teksnya termuat dalam 122 halaman, yang terdiri daripada berbagai-bagai topik perbincangan. Boleh dikatakan bahawa teks ubat bedil ini terkandung dalam bahagian (atau himpunan) karangan yang menerangkan jenis-jenis ilmu pertukangan dan kemahiran tertentu yang bersifat praktis. Seluruh karangan ini muncul atau tertulis selepas teks tentang pedoman surat-menyurat, bermula pada halaman 111. Terdapat berbagai keterangan tentang cara mempateri, membuat dakwat, mencampur minyak, menukang aloi dan emas, menatah batu permata dan membuat perkakas masak. Cara membuat ubat bedil dinyatakan dalam muka surat 118-122, sebelum diakhiri dengan kolofon manuskrip. Berdasarkan kolofon, dapat diketahui bahawa seluruh teks yang ada telah disalin oleh Muhammad Saidi bin Maidin dari Melaka pada 3 Rabiulawal tahun 1303 (1886 Masehi). Manuskrip ini terdiri daripada sejumlah 122 muka surat, yang menggunakan kertas Eropah bersaiz 22 x $16 \mathrm{~cm}$ dengan tera air 'Superfine 1882'. Setiap muka surat tertera 15 baris ayat yang ditulis dengan huruf Jawi yang sangat kemas dan mudah dibaca. Setiap permulaan bab ditandakan dengan rubrikasi. Menurut Ricklefs et al. (2014, p. 160), manuskrip ini dibeli daripada Kegan Paul.

\subsection{8 (Petua)}

Manuskrip ini disimpan di Perpustakaan Bahagian Sejarah, Muzium Negeri Terengganu yang dikatalogkan dengan nombor 85.48 dengan judul 'Petua Menembak Meriam Istinggar' (Katalog Induk Manuskrip Melayu, 1993). Pada kulit manuskrip ini tertera ayat 'Ini Buku Fasal Tembak Menembak Meriam Setinggar Melayu yang Dahulu-dahulu' dalam huruf Jawi. Setakat ini, belum diketahui informasi tentang penyalinan atau pentarikhannya. Petua pada asalnya merupakan hak milik seorang yang bernama Haji Muhammad dari Terengganu, tetapi kemudian berjaya diperolehi oleh Muzium Negeri Terengganu pada Jun 1985 (Wan Mohd Dasuki, 2012, p. 133). Dalam suatu dokumen lain yang ditampal pada manuskrip ini, tertulis nama Tengku Sulaiman bin Sultan Zainal Abidin (Terengganu) dan di bawahnya terdapat rajah tapak tangan serta tulisan Jawi. Dalam suatu helaian yang lain, tercatat tarikh 15 Ramadan 1344 (1926 Masehi). Helaian 
ini memuatkan keterangan tentang 'Rupa Khatamun Nubuwwah yang Antara Dua Belikat Nabi s.a.w'. Walau bagaimanapun, keterangan itu tidak dapat dihubungkan secara langsung kerana dokumen-dokumen terbabit hanya ditampal atau terselit dalam manuskrip berkenaan yang sebenarnya merupakan sejenis buku tulis. Apatah lagi, perkara yang tertulis pada dokumen-dokumen itu tidak relevan dengan isi kandungan Petua yang menerangkan tentang cara-cara penggunaan senjata api.

Isi kandungan Petua dikatakan memiliki pertalian dengan tiga buah manuskrip lain, terutama MS 31 yang disimpan oleh Dewan Bahasa dan Pustaka, Kuala Lumpur (Wan Mohd Dasuki, 2012, p. 137-139). Dua buah bahan yang lain pula ialah MS 101 (yang juga berada di Dewan Bahasa dan Pustaka), dan MSS 1380 yang berada di Perpustakaan Negara Malaysia. Namun, kaitan antara MSS 1380 adalah cukup kecil, iaitu daripada segi gaya bahasa mantera menembak yang turut dimuatkan dalam teks Petua. Begitu juga dengan MS 101, hubungan tekstualnya dijelaskan dengan deskripsi ritual penunang peluru bedil berdasarkan penggunaan sejenis tumbuhan yang mampu menghasilkan minyak, iaitu pohon jarak Burma. Dengan demikian, kaitan antara Petua dengan MS 31 dilihat paling signifikan. Kedua-dua manuskrip ini menghuraikan amalan penggunaan bedil yang diistilahkan sebagai istinggar, iaitu sejenis senapang yang menggunakan alat pencucuh sumbu (matchlock mechanism). Boleh dilihat bahawa terdapat banyak persamaan yang terjadi antara kedua-dua bahan ini, sehingga Wan Mohd Dasuki (2012, p. 137) beranggapan bahawa MS 31 merupakan sumber bagi Petua dengan beberapa modifikasi tertentu. Kedua-dua manuskrip ini mengandungi unsur dialek Kelantan atau Patani yang sekata.

Namun begitu, perbezaan unsur yang paling ketara antara Petua dengan manuskripmanuskrip ilmu bedil yang lain ialah keterangan mengenai campuran ramuan ubat bedil. Teks ubat bedil ini dicatatkan dalam beberapa muka surat terakhir manuskripnya yang merupakan satu daripada ciri penting teks Petua yang masih belum ditemukan pada manuskrip lain, kecuali sebahagian daripadanya terdapat pada lima muka surat yang terakhir teks Adat.

Petua wujud dalam rupa sebuah buku tulis yang masih lagi utuh jilidnya, dan dibalut oleh kulit keras (kadbod), sama seperti Adat. Tebal jilid buku ini adalah sekitar 1.2 cm dengan saiz kertas 17 x $11.5 \mathrm{~cm}$. Teks Petua ditulis dalam 40 muka surat dengan berkeadaan baik dan hampir kebanyakannya boleh dibaca dengan jelas, kecuali beberapa baris ayat dalam halaman tertentu. Setiap muka surat termuat 12 baris ayat yang ditulis langkau sebaris. Pada kertas manuskrip ini terdapat tera air Britannia di bahagian tengah buku, tetapi tidak disertai dengan apa-apa tarikh atau keterangan lain.

\section{Hasil Transliterasi}

Kerja-kerja transliterasi kedua-dua bahan manuskrip ini dilakukan secara sederhana dengan mengutip bahagian-bahagian yang telah dikenal pasti memuatkan keterangan tentang ramuan ubat bedil. Justeru, transliterasi teks Adat hanya melibatkan muka surat 118-122, iaitu lima halaman terakhir manuskrip berhubung subjek yang dikaji. Sementara untuk manuskrip Petua pula hanya melibatkan halaman 34-37, atas faktor yang sama. Transliterasi dibuat dengan menukarkan ejaan Jawi lama dalam teks-teks tersebut sedekat mungkin dengan bentuk ejaan asal, tetapi sesetengahnya disesuaikan dengan sistem bahasa Melayu moden menurut cara penggunaan huruf rumi. Dalam proses ini juga, digunakan 
sejumlah tanda baca seperti titik, koma dan titik koma untuk mempermudahkan bacaan, tanda garis miring untuk membezakan setiap baris ayat dan nombor muka surat mengikut manuskrip asal, sementara tanda kurung pula untuk menunjukkan perkataan yang mungkin tertinggal. Kesemua tanda ini dimasukkan untuk membolehkan pembaca melakukan rujukan silang ketika membandingkan hasil transliterasi ini dengan teksnya yang asal, jika perlu. Berikut dipaparkan hasil transliterasi teks Adat dan Petua.

Jadual 1: Perbandingan hasil transliterasi teks Adat dan Petua

\begin{tabular}{|c|c|}
\hline Adat & Petua \\
\hline $\begin{array}{l}\text { Pasal pada menyatakan berbuat ubat bedil. Bermula } \\
\text { berbuat ubat setinggar; pertama /118/ } \\
\text { sendawanya dua timbang dan belerangnya } \\
\text { setimbang dan harangnya dan airnya arak api. / } \\
\text { Sebagai lagi berbuat ubat bedil besar. Sendawanya } \\
\text { lima timbang dan belerangnya setimbang / } \\
\text { dan airnya arak api juga. Sebagai lagi berbuat ubat } \\
\text { penggalak. / } \\
\text { Pertama, sendawanya lima tahil dan belerangnya } \\
\text { lima belas emas dan berat / } \\
\text { harangnya setahil. Sebagai lagi jika hendak berbuat } \\
\text { banyak, timbang tiga timbang, / } \\
\text { jadikan sela selang atau timbang sekali. Sendawanya } \\
\text { dua puluh tahil dan / } \\
\text { belerangnya kurang sepaha empat tahil, dan } \\
\text { harangnya empat tahil. Akan hal / } \\
\text { masaknya, sekira-kira hendak halus sendawanya itu, } \\
\text { maka turutkanlah. / } \\
\text { Sebagai lagi, peri membuat ubat istinggar. Pertama, } \\
\text { sendawanya sekati dan belerangnya / } \\
\text { empat tahil, dan harangnya tengah empat tahil. } \\
\text { Sebagai lagi, sendawanya / } \\
\text { dua belas tahil, belerangnya dua tahil sepaha, dan } \\
\text { harangnya dua tahil. / } \\
\text { Dan lagi, suatu jenis ubat jualan. Sendawanya tujuh } \\
\text { tahil dan / } \\
\text { harangnya setahil dan belerangnya setahil. Dan } \\
\text { sejenis lagi pulak, sendawanya / } \\
\text { itu tujuh tahil dan harangnya setahil tebang belah } \\
\text { dan belerangnya setahil sepaha. / } \\
\text { Dan sejenis lagi pulak, sendawanya tujuh tahil dan } \\
\text { harangnya setahil lima /119/ } \\
\text { kupang dan belerangnya lima belas emas. Dan } \\
\text { sejenis lagi pulak, berbuat ubat / } \\
\text { sendawanya tujuh tahil dan belerangnya setahil dan } \\
\text { arangnya. Dan satu jenis lagi berbuat ubat istinggar } \\
\text { timbang dengan dacing Cina. / } \\
\text { Jika sendawanya sekati, belerangnya dua tahil } \\
\text { seemas Cina dan harangnya / } \\
\text { tengah tiga tahil Cina. Dan sejenis lagi pulak, } \\
\text { sendawanya dua belas / } \\
\text { tahil dan belerangnya dua tahil dan harangnya dua } \\
\text { dak, sendawanya sepuluh tahil } \\
\text { dangan. Bermula / }\end{array}$ & $\begin{array}{l}\text { Pasal ini peri berbuat ubat istinggar cara } \\
\text { Minangkabau yang disukat. Pertama-tama sendawa } \\
\text { sesukat / } \\
\text { belerang setengah sukat, harang tengah dua sukat. } \\
\text { Sebagai lagi ubat istinggar / } \\
\text { sendawa } 9 \text { tahil, belerang tengah empat tahil, harang } \\
4 \text { tahil. Sebagai pula sendawa / } \\
9 \text { tahil, belerang tengah dua tahil, harang } 4 \text { tahil } \\
\text { seemas. Sebagai pula sendawa / } \\
\text { sekati, } 4 \text { tahil belerang, } 4 \text { tahil harang. Sebagai pula } \\
\text { ubat istinggar, pertama / } \\
\text { harang kurang sepaha } 4 \text { tahil, belerang } 4 \text { tahil } \\
\text { sepaha, sendawanya sekati. Sebagai / } \\
\text { pula ubat bedil sendawanya } 2 \text { sukat, belerang suatu } \\
\text { [sukat], harang tengah tiga / } \\
\text { sukat. Sebagai pula ubat meriam sendawa } 4 \text { sukat, } \\
\text { belerang } 2 \text { sukat, harang / } \\
\text { tengah } 4 \text { sukat. Inilah perbuatan cara Minangkabau. } \\
\text { Sebagai pula tembakan ubat bedil / } \\
\text { cara Minangkabau; sendawa sekati, belerang } 4 \text { tahil, } \\
\text { harang tengah empat tahil. Sebagai / } \\
\text { pula ubat bedil cara Wolanda. Pertama-tama; } \\
\text { sendawa sekati, belerang } 4 \text { tahil, harang / } \\
\text { pun } 4 \text { tahil juga. Sebagai pula ubat cara Inggeris. } \\
\text { Pertama; sendawa /34/ } \\
\text { sekati, belerang } 5 \text { tahil, harang } 4 \text { tahil. Sebagai pula } \\
\text { ubat bedil cara Peringgi; / } \\
\text { sendawa sekati, belerang tengah } 5 \text { tahil, harang } 4 \\
\text { tiga mas; mahahil. Sebagai pula ubat / } \\
\text { tiga ratus sembilan puluh depa. Sebagai pula jika } \\
\text { bedil cara Jepun; sendawa sekati, belerang } 4 \text { tahil, } \\
\text { harang tengah empat tahil. Sebagai / } \\
\text { pula ubat istinggar yang dikehendaki khari. Pertama; } \\
\text { jika sendawa } 4 \text { tahil, belerang } 2 \text { / } \\
\text { tahil } 2 \text { mas, harang setahil } 3 \text { mas; makan pelurunya } \\
\text { empat ratus delapan / } \\
\text { puluh depa. Sebagai pula sendawa } 4 \text { tahil, belerang } \\
2 \text { tahil, harang setahil sepaha; / } \\
\text { makan pelurunya empat ratus delapan puluh tujuh } \\
\text { depa. Sebagai pula sendawa } 4 \text { tahil, / } \\
\text { belerang setahil sepaha, harang } 2 \text { tahil } 2 \text { mas; makan } \\
\text { telurunya dua ratus / }\end{array}$ \\
\hline
\end{tabular}


sendawanya sembilan belas tahil, dan harangnya empat tahil lima emas /

dan belerangnya tiga tahil tiga emas. Dan sejenis pulak, sendawanya /

sembilan belas tahil dan harangnya setahil tujuh emas dan /

belerangnya setahil tiga emas. Dan sejenis lagi, sendawanya /

lima belas tahil dan harangnya dua tahil tiga emas dan belerangnya /

setahil lima emas lima hun. Dan sejenis lagi, sendawanya dua puluh satu /120/

tahil, dan harangnya empat tahil tiga emas dan belerangnya dua tahil tiga /

emas satu hun. Dan lagi sejenis lagi, sendawanya dua puluh tahil lima mas, /

dan harangnya empat tahil lima emas dan

belerangnya tiga tahil lima emas. /

Dan sejenis lagi, sendawanya enam tahil sepaha dan belerangnya setahil /

seemas dan arangnya setahil tujuh timbang jadikan selang. Hanya Minangkabau /

dengan Jepun sama timbang. Dan sebagai lagi, sendawanya sekati dan /

harangnya empat tahil dan belerangnya tengah empat tahil. Bahawa timbangan orang /

Inggeris dan Peringgi sama timbangnya. Dan satu jenis lagi, sendawanya sekati /

dan belerangnya lima tahil dan harangnya empat tahil. /

Dan sejenis lagi pulak, jika enam ratus timbangnya sendawanya, lima kati /

Cina harangnya, dan belerangnya sembilan tahil. /

Dan sejenis lagi pulak, jika lima ratus [timbang]

sendawanya dan lima kati harangnya /

dan belerangnya tujuh tahil. Dan jika empat ratus

sendawanya, lima kati tiga /

tahil harangnya dan tiga belas tahil sepuluh emas belerangnya. Dua paha /

emas belerangnya dua tahil 15 emas. Dan jikalau berbuat pilurunya kurang /121/

dua kupang tebang belah, dan berat ubatnya kurang dua kupang sepaha. Berat pilurunya /

enam kupang dan berat ubatnya seemas.

Demikianlah adanya, wallahuaklam. /122/ sendawanya sepuluh /35/

tahil, belerang 3 paha 2 mas, harangnya setahil

sepuluh mas; makan pelurunya /

325 depa. Sebagai pula jika sendawanya setahil,

belerang setahil, harangnya /

setahil sepaha; makan pelurunya 387 depa. Sebagai

pula; jika sendawanya /

sepuluh tahil, belerang 2 tahil tiga emas, harang 2

tahil lima emas; makan pelurunya /

374 depa. Sebagai pula jika sendawanya sepuluh

tahil, belerang dua tahil, /

harangnya tengah dua tahil; makan pelurunya 335

depa. Sebagai pula; jika sendawanya /

lima belas tahil, belerang dua tahil sepaha,

harangnya dua tahil; makan pelurunya tiga /

ratus empat puluh tiga depa dengan dua hasta.

Sebagai pula; jika sendawanya /

lima belas tahil, belerangnya tengah dua tahil,

harangnya dua tahil tebang belah; makan /

pelurunya tiga ratus delapan puluh lima depa tiga

hasta. Sebagai pula; /

jika sendawanya tiga belas tahil maka harangnya

sepuluh paha, belerang setahil /

sepaha; makan pelurunya empat ratus sembilan

puluh dua hasta enam jari /36/

dengan galaknya. Sebagai pula; jika sendawanya

tengah tiga puluh tahil, harangnya /

tengah tujuh tahil, belerangnya lima tahil; makan

pelurunya empat ratus enam puluh /

[depa] sembilan jari. Sebagai pula; jika sendawanya tengah tiga tahil tiga emas, /

harangnya tengah empat tahil tiga emas; makan pelurunya empat ratus enam puluh /

depa. Sebagai pula akan penggalaknya; sendawanya setahil, belerangnya enam kupang, /

harangnya sepuluh kupang. Sebagai pula akan

penggalaknya; sendawanya sekati, belerangnya / sepuluh paha, harangnya empat tahil. Pasal ubat yang tiada berketahuan /

itu; sendawanya 3 tahil, harangnya empat tahil, belerang kurang dua emas 3 tahil. /

Ketahui hai ikhwani, adapun akan hal membuat ubat yang baik itu maulah /

enam syarat. Maka baik ubat. Pertama; dikenal

arang yang baik. Kedua; mengenal belerang yang

baik. /

Ketiga; mengenal sendawa yang baik. Keempat;

mengetahui menurunkan air ke dalam belanga.

Kelima; tahu /

akan masaknya. Keenam; tahu akan lumatnya.

Demikianlah adanya, tammatulkalam. /37/

\section{Perbincangan}

Berdasarkan pembacaan filologi, kedua-dua teks memperlihatkan keunikan dan keistimewaan aspek tekstual yang tersendiri. Meskipun kedua-duanya mengandungi bentuk dan pola perbincangan yang hampir-hampir sama, namun, teks Adat dan Petua mempunyai pelbagai ciri perbezaan. 
Secara umum, perbincangan yang cuba diketengahkan dalam kajian ini ialah berkenaan sifat dan dimensi permukaan teks manuskrip yang mempengaruhi cara-cara teks-teks ini diperturunkan. Selain itu, perkara yang lebih penting lagi adalah tentang tradisinya, iaitu cara-cara korpus ilmunya memberikan contoh-contoh huraian yang bersifat numerikal dan kuantitatif. Jika diperhatikan, rata-rata huraiannya menggunakan jenis atau bentuk bahasa yang ringkas, padat dan kemas, biarpun wujud pernyataan-pernyataan yang agak mengelirukan, berkemungkinan berpunca daripada masalah penyalinan. Permulaan teksnya menggunakan frasa 'pasal pada menyatakan', atau 'pasal ini peri' yang kemudian disambung dengan 'sebagai pula', 'sebagai lagi', 'sejenis lagi', atau 'dan lagi', yang bukan hanya menunjukkan wujudnya kepelbagaian maklumat (data) berhubung ramuan-ramuan ubat bedil yang diperturunkan, bahkan mengenai aras (level) maklumat yang dinyatakan untuk menampilkan intensiti atau sukatan ubat bedil. Hal ini mungkin juga sedikit sebanyak akan dapat menerangkan kesedaran penulis atau penyalinnya berhubung ketepatan jumlah dan jenis kandungan ramuan ubat bedil itu, yang memerlukan susunansusunan kerana sesetengahnya agak rumit untuk diingati.

Dalam konteks ketepatan ini, memperlihatkan pula cara-cara angka-angka (seperti yang dapat diperhatikan dalam Petua) digunakan untuk mempresentasi jumlah dan jenis kandungan itu, di samping penggunaan ejaan untuk angka-angka berkenaan. Begitu juga dalam aspek takaran, disebut secara langsung peralihannya daripada jenis timbangan (dacing) yang umum kepada jenis timbangan yang khusus (dacing Cina) (Adat, p. 120). Hal ini secara jelas menunjukkan aspek kuantitatif memainkan peranan signifikan dalam wacana tekstual ramuan ubat bedil, suatu bentuk penghuraian yang agak berlainan dalam jenis-jenis teks ilmu bedil yang lain, meskipun kekal dalam maksud wacana yang instruktif sifatnya. Berdasarkan wacana instruktif, huraian-huraian dalam teks bersifat langsung (direct), tidak lewah dengan berbagai-bagai ungkapan yang lazim mengisi struktur ayat sesebuah karangan tradisional. Terdapat sekurang-kurangnya tiga gaya ujaran yang paling umum dinyatakan dalam teks, dengan jelas menonjolkan aspek kuantitatif dalam keilmuan tradisional, khasnya seperti yang ditampilkan oleh penggunaan angka-angka kardinal dan ordinal (Shaharir, 2013):

a. pernyataan langsung: "sendawanya sekati dan belerangnya empat tahil, dan harangnya tengah empat tahil" (Adat, p. 119), yang menunjukkan penggunaan angka atau pengejaan angka kardinal secara terus dan jelas (1 kati sendawa +4 tahil belerang + 3.5 tahil arang)

b. pernyataan perbandingan: "jika sendawanya tengah tiga tahil tiga emas, harangnya tengah empat tahil tiga emas; makan pelurunya empat ratus enam puluh depa (Petua, p. 37). Pernyataan ini melibatkan hubungan dua atau lebih variabel yang secara logiknya diperhatikan daripada segi timbangan (berat tahil atau emas) dengan ukuran (jarak depa).

c. pernyataan prosesual (langkah demi langkah): “...adapun akan hal membuat ubat yang baik itu maulah enam syarat, maka baik ubat..." (Petua, p. 37). Pernyataan seperti ini menerangkan suatu kedudukan relatif tentang proses membuat ubat bedil dalam urutan keseluruhan, dengan melibatkan penggunaan sistem angka ordinal.

Di samping pernyataan-pernyataan instruktif dan kuantitatif seumpamanya, teks turut menggunakan deskripsi secara langsung untuk menyebut tentang butiran ramuan ubat bedil yang diperturunkan. Deskripsi ini terutama sekali merujuk asal-usul ramuan yang digunakan dengan penanda tertentu, misalnya nama-nama seperti Raja Jepun, Minangkabau, Wolanda (Belanda) dan seterusnya. Namun begitu, unsur-unsur numerikal daripada penanda-penanda ini tidak seharusnya diterima begitu sahaja, malahan perlu 
diteliti dengan memperbandingkan ramuan-ramuan itu berdasarkan sumber-sumber luar (bukan manuskrip).

Secara keseluruhan, teks ubat bedil dalam kedua-dua manuskrip yang dikaji dilihat berfungsi dalam membincangkan ramuan ubat bedil menurut beberapa aspek berikut:

1. Ramuan ubat bedil untuk istinggar

Hampir kesemua catatan ramuan ubat bedil yang dijelaskan dalam teks-teks ini adalah untuk kegunaan bedil setinggar atau istinggar. Dalam teks ilmu bedil, istinggar dengan lebih lengkap dinyatakan dalam istilah istinggar Minangkabau. Jenis bedil ini memang dikatakan sebagai buatan Minangkabau (Wan Mohd Dasuki dan Othman Yatim, 2013). Justeru, hal ini kemungkinan dapat memberikan erti pula mengapa keseluruhan ramuan ubat bedil istinggar yang tercatat adalah buatan Minangkabau yang dibandingkan dengan jenis-jenis ubat bedil lain, contohnya dari Jepun. Teks Adat berisi 22 formula campuran ramuan untuk dijadikan ubat bedil. Formula ini terdiri daripada sendawa (potasium nitrat), belerang (sulfur) dan arang, tetapi nampaknya sejenis bahan yang asing (mungkin dalam hal ini juga memperlihatkan pengubahsuaian dan adaptasi lokal), iaitu arak api turut digunakan sebagai satu daripada unsur pembuatannya. Sementara itu, teks Petua pula menunjukkan sedikit kelainan dengan yang terdapat dalam ramuan ubat bedil meriam. Teks ini hanya mencatat 11 formula membuat ubat bedil bagi kegunaan istinggar. Berdasarkan seluruh ramuan yang diberikan, pembuatan ubat bedil ditentukan menurut jumlah sukatan yang telah ditetapkan. Sukatan-sukatan ini mengaplikasi unit-unit ukuran berat seperti kati, tahil, emas, paha, dan hun dengan jumlah yang bervariasi dan pelbagai.

2. Ramuan untuk penggalak (priming powder)

Ubat bedil dan penggalak berasal daripada bahan yang sama, tetapi mempunyai bentuk dan fungsi yang berbeza. Penggalak lazimnya digiling atau dimasak sehingga butirannya lebih halus untuk sifat cepat rebak (deflagrasi) (Wan Mohd Dasuki, 2013). Hal ini kerana penggalak dimasukkan ke lubang bedil tempat pencucuh dinyalakan, untuk berfungsi merebakkan pembakaran pertama dalam lubang bedil supaya nyalaan tercetus pada ubat bedil dan seterusnya meledakkan tembakan. Ubat bedil pula dimasukkan ke dalam bedil menerusi muncungnya sebelum dimasukkan peluru, serta diradak sehingga mampat. Teks Adat menunjukkan dua formula yang masing-masing berbeza daripada segi komposisi isi kandungan dan proses pembuatan. Formula yang pertama; dengan menggunakan 5 tahil sendawa, 15 emas belerang dan 1 tahil arang dapat diganda menjadi tiga kali, jika hendak membuatnya dalam kuantiti yang besar sama ada dicampurkan serentak atau diasingkan (tiga kali proses yang sama). Satu lagi formula menunjukkan kadar jumlah yang agak besar daripada segi komposisi kandungan bahannya, dengan menggunakan 20 tahil sendawa bersama 4 tahil belerang yang kemudian dikurangi sebanyak 1 paha, dan 4 tahil arang. Formula penggalak teks Petua juga disebutkan dalam bentuk komposisi menurut jumlah. Komposisi pertama lebih sedikit, iaitu 1 tahil arang, 6 kupang belerang dan 10 kupang arang, berbanding komposisi kedua dengan 1 kati sendawa, 10 paha belerang dan 4 paha arang. Dengan itu, penggalak terhasil dalam dua keadaan; pertama, secara pukal (jumlah banyak), dan kedua; dengan jumlah yang lebih kecil. Jumlah kecil ini barangkali dapat dihubungkan pula untuk kegunaan peribadi.

3. Ramuan yang mengimbangkan berat peluru dengan ubat bedil

Dalam teks Adat, terdapat pula dua senarai ramuan yang digunakan untuk mengimbangi berat sebutir peluru yang hendak ditembak. Berat ini ini disetarakan dengan jumlah berat ubat bedil. Dalam formula pertama; dinyatakan bahawa sekiranya berat peluru itu kurang 2 kupang, maka ubat bedil yang diperlukan ialah kurang 
daripada 2 kupang juga, tetapi dilebihkan 1 paha. Dalam formula yang kedua; jika berat peluru sebanyak 6 kupang maka ubat bedilnya sebanyak 1 emas. Imbangan berat yang dicadangkan itu merujuk pada berat ubat bedil yang bersesuaian untuk menghasilkan pembakaran yang dapat meledakkan sebutir peluru. Peluru istinggar lazimnya diperbuat daripada timah atau plumbum yang dituang menurut saiz dan berat tertentu, tetapi sehingga kini masih belum ditemukan bukti standardisasi berat sebagaimana mengikut cara pembuatan peluru bedil di Eropah. Jika ubat bedil memiliki formulanya, maka tidak mustahil juga peluru dituang mengikut formula berat tertentu. Walau bagaimanapun, perkara mengenai berat peluru ini tidak dijelaskan dalam teks Petua.

4. Ramuan yang mempengaruhi jarak tembakan

Perkara lain yang dijelaskan dalam teks Petua adalah berhubung jarak tembakan. Dalam konteks ini, terdapat jangkaan-jangkaan tertentu berhubung jarak peluru untuk sampai ke sasarannya setelah ditembak menggunakan ubat bedil tertentu. Menerusi teks Petua, didapati sejumlah 14 formula ubat bedil yang dapat menerangkan tentang jarak (yang mungkin dimaksudkan adalah jarak jatuhnya peluru dan bukan jarak efisien tembakan), yang diistilahkan sebagai 'makan peluru' (Shaharir, 2013, p. 114). Contohnya, tembakan sejauh 480 depa memerlukan formulasi 4 tahil sendawa, 2 tahil 2 emas belerang, dan 1 tahil 3 emas arang (Petua, 35). Dalam perkiraan Wan Mohd Dasuki (2013, p. 204), jarak 480 depa jika ditukarkan ke dalam sistem metrik adalah lebih kurang 870 meter. Ramuan ubat bedil yang diperlihatkan daripada segi jarak bedilan atau makan peluru ini pula tidak tercatat dalam Adat.

5. Instruksi membuat ubat bedil

Teks Petua juga menunjukkan tentang beberapa keadaan tertentu untuk membuat ubat bedil yang berkualiti. Terdapat enam keadaan yang perlu dipatuhi oleh pembuat ubat bedil berdasarkan urutan prosesnya, iaitu mengetahui jenis-jenis arang, belerang, dan sendawa yang sesuai untuk dijadikan ubat bedil (proses 1-3), cara memasukkan air ke dalam bekas untuk mengaduk campuran ketiga-tiga bahan (proses 4), cara memasaknya (proses 5), dan mengetahui bahawa keadaan ubat bedil itu sudah sebati (proses 6) (Petua, p. 37). Dalam hal ini, keenam-enam proses berkenaan dapat membuktikan bahawa ubat bedil tersebut dimasak, atau dengan istilah yang digunakan dalam teknologi ubat bedil Eropah disebutkan sebagai 'corning'. Tujuannya adalah untuk membolehkan bahan-bahan tersebut benar-benar sebati, justeru akan dapat menghasilkan pembakaran yang lebih sempurna (Wan Mohd Dasuki, et al., 2012). Instruksi pembuatan ubat bedil ini juga tidak terkandung dalam teks Adat.

Di sebalik rangkuman deskripsi ubat bedil sebagaimana yang telah diperlihatkan oleh kedua-dua teks itu, proses mencampurkan ramuannya mengikut sukatan yang telah digariskan tidak diberikan penjelasan. Dengan erti kata lain, teks mengenai langkahlangkah kerja untuk membuat ubat bedil secara keseluruhan sehingga siap digunakan, belum ditemukan sehingga kini. Hanya ramuan ubat bedil sahaja yang diketahui. Hal ini bererti kaedah pembuatan ubat bedil Melayu masih menjadi rahsia. Walaupun begitu, berdasarkan sejumlah keterangan yang dikutip dalam teks Petua, adalah dipercayai bahawa ubat bedil Melayu turut menggunakan teknik pembuatan sama seperti ubat bedil orang Eropah. Cuma, prosedurnya tidak diketahui dengan tepat dan sejauh mana berlakunya proses pengubahsuaian dan adaptasi teknologinya sehingga hal ini memerlukan penggalian lebih lanjut. Usaha ini sudah tentu memerlukan kajian yang bersifat komparatif, iaitu dengan membandingkan ramuan ubat bedil yang ada dengan kajian-kajian tentang ubat bedil dalam kebudayaan-kebudayaan lain, misalnya Dinasti Ming (China), Jepun atau Eropah. Proses perbandingan ini seharusnya mengambil kira aspek kuantitatif yang 
diwakili oleh angka-angka kardinal dalam sukatan yang diberikan. Namun begitu, pemerhatian yang dilakukan buat masa ini belum dapat memberikan pencerahan yang secukupnya, terutama daripada segi konsep-konsep yang dibangunkan menerusi kedua-dua teks yang dapat menunjukkan sifat, ciri atau elemen khusus ubat bedil Melayu.

\section{Kesimpulan}

Teks ubat bedil merupakan antara hasil persuratan tradisional yang digolongkan ke dalam karya-karya bersifat kepustakaan ilmu, atau lebih tepatnya sebagai sebahagian daripada kelompok teks ilmu bedil. Sehingga kini, masih belum banyak teks dan sumber-sumber pendokumentasian yang dijumpai yang mengupas secara mendalam tentang pembuatan ubat bedil Melayu. Walaupun begitu, dengan sumbangan lebih daripada 1000 patah kata dalam deskripsi ubat bedil oleh kedua-dua teks Adat dan Petua ini, setidak-tidaknya telah dapat menggariskan beberapa hal yang patut difokuskan khasnya untuk kajian lanjutan. Antaranya, kedua-dua teks ini menunjukkan adanya dinamika tekstual berdasarkan kedekatan hubungannya, yang dapat dikesan melalui susunan formula, bentuk wacana, jenis dan bentuk takaran, begitu juga dengan angka-angka yang diberikan. Selain itu, kedua-dua teks juga menunjukkan bahawa deskripsi ubat bedil yang dapat diketahui sekarang, lebih membincangkan ramuan ubat bedil untuk kegunaan istinggar (Minangkabau), iaitu sejenis bedil berpencucuh sumbu. Terdapat pula beberapa ramuan untuk penghasilan serbuk penggalaknya, di samping ramuan untuk mengimbangkan antara berat peluru dengan ubat bedil yang dimasukkan ke dalam bedil, ramuan bedil untuk mencapai jarak tembakan tertentu, dan keadaan yang diperlukan dalam proses membuat ubat bedil. Namun begitu, tiada penjelasan tentang proses mencampurkan bahan sendawa, belerang dan arang mengikut ramuan atau formula yang diperturunkan itu. Pada masa yang sama, kedua-dua teks memperlihatkan keseluruhan isi kandungan yang secara langsung menampilkan sifat wacana yang instruktif dan kuantitatif sebagaimana yang dapat dikenal melalui tiga bentuk pernyataan tekstual, iaitu secara langsung, perbandingan dan prosesual. Berdasarkan ketiga-tiga aspek ini, aspek kuantitatif memainkan peranan aktif dalam wacana teks ubat bedil yang menampilkan karakteristik tekstual yang berbeza berbanding jenis-jenis teks ilmu bedil yang lain.

Walau bagaimanapun, kajian-kajian lanjutan amat diperlukan untuk mendalami lagi pengetahuan berhubung teks-teks seperti ini, terutama sekali merungkai unsur-unsur pengaruhnya dalam pembentukan wacana instruktif dan kuantitatif tradisi ilmu tersebut. Jika sebelum ini karya-karya ilmu tradisional lebih cenderung untuk difahami dalam konteks mistik, kajian teks ubat bedil diharap akan dapat memberikan jalan baharu untuk lebih memahami kedudukan dan representasi bentuk-bentuk kuantitatif yang sama sekali tidak boleh diabaikan sebagai satu daripada bentuk kandungan utama dalam teks-teks ilmu tradisional yang majoritinya tersalin dalam manuskrip-manuskrip Melayu.

\section{Glosari}

Arak api - sejenis minuman keras diperbuat daripada nira kelapa, yang dipercayai bertujuan untuk memanaskan lagi pembakaran ubat bedil. 
Khari - kemungkinan dapat difahami sebagai 'gori'; menguntungkan, atau mengena (daripada segi impak tembakan).

Selaselang - sela (lat) dalam proses membuat ubat bedil, atau diasingkan (tidak dicampurkan sekali).

Tebang belah - kemungkinan dapat dirujuk sebagai unit sukatan khas pada tahil (tahil tebang belah).

Ubat jualan - jenis ubat bedil yang diperdagangkan.

\section{Rujukan}

Adat segala Raja-raja Melayu (MS 36497). (1886). Perpustakaan School of Oriental and African Studies, Universiti London.

Harun Mat Piah et al. (2006). Kesusasteraan Melayu tradisional. Kuala Lumpur: Dewan Bahasa dan Pustaka.

Katalog induk manuskrip Melayu. (1993). Kuala Lumpur: Perpustakaan Negara Malaysia.

Mohd Anuar Ramli, Mohammad Aizat Jamaluddin, Muhammad Ikhlas Rosele, dan Mohd Akmal Sidik. (2016). Sumbangan ulama Melayu klasik dalam pembinaan kearifan tempatan di alam Melayu. Jurnal Pengajian Melayu 27(1), pp. 180-198.

Muhamad Shafiq Mohd Ali. (2020). Teknologi masyarakat Minangkabau dalam perang Padri di Sumatera Barat. International Journal of the Malay World and Civilisation 8(3), pp. 43-53.

Norafifah Abd Hamid, Nor Hayati Md Dahlal, Rahimin Affandi Abd. Rahim \& Zainal Abidin Borhan. (2011). Kerangka epistemologi Melayu Islam dan kaitannya dengan konsep sains: Satu analisis. Jurnal Pengajian Melayu 22(1), pp. 234-269.

Nor Farhana Che Mat, Filzah Ibrahim, dan Rusmadi Baharuddin. (2018). Menelusuri budaya literasi masyarakat Melayu melalui kajian manuskrip ilmu bedil." Manuskripta 9(1), pp. 137-167.

Petua menembak meriam istinggar (85.48). (tidak bertarikh). Perpustakaan Bahagian Sejarah Lembaga Muzium Negeri Terengganu, Kuala Terengganu.

Pramono, Wan Mohd Dasuki Wan Hasbullah \& Herry Nur Hidayat. (2015). Mysticism elements in the use of firearm technology in the manuscripts on firearms. Humaniora 27(3), pp. 373-383.

Ricklefs, M.C., Voorhoeve, P. \& Gallop, A.T. (2014). Indonesian manuscripts in Great Britain: A catalogue of manuscripts in Indonesian languages in British public collections. Jakarta: Ecole française d'Extrême-Orient, Perpustakaan Nasional Republik Indonesia dan Yayasan Pustaka Obor Indonesia.

Sevea, T.S. (2020). Miracles and material life: Rice, ore, traps and guns in Islamic Malaya. Cambridge: Cambridge University Press. 
Shaharir Mohamad Zain. (2013). Istilah dan konsep pengukuran tradisional alam Melayu. Pulau Pinang: Penerbit Universiti Sains Malaysia.

Sudjiman, P.H.M. (1979). Adat raja-raja Melayu: A critical edition together with a commentary on court ceremonials described [Unpublish doctoral dissertation], Australian National University.

Wan Mohd Dasuki Wan Hasbullah. (2012). Naskhah 85.48: Manuskrip ilmu menembak dari Terengganu. Jurnal Filologi Melayu, 19, pp. 130-144.

Wan Mohd Dasuki Wan Hasbullah. (2013). Pengetahuan dan teknologi Melayu berhubung penggunaan senjata api: Analisis naskhah ilmu bedil (Disertasi sarjana yang tidak diterbitkan), Universiti Malaya.

Wan Mohd Dasuki Wan Hasbullah, Ahmad Hakimi Khairuddin, dan Siti Radziah Mustafa. (2012). Gunpowder technology: General remarks from malay manuscripts MSS 31 and MSS 85.48. Dlm. UM-TU-UGM: 1st International Conference on Southeast Asian Language and Culture (ed. Chaiwat Meesantan), pp. 82-95. Bangkok: Thammasat University.

Wan Mohd Dasuki Wan Hasbullah \& Othman Yatim. (2013). Teknologi istinggar: Beberapa ciri fizikal dalam aplikasi teknikalnya. International Journal of the Malay World and Civilisation, 1(3), pp. 51-59. 